Surgery in the Pennsylvania Hospital. By THOMAs G. Morton, M.D., and William HuNT, Mi.D., Surgeons to the Hospital. Prepared by direction of the Managers of the Hospital. Philadelphia : J. B. Lippincott and Co. 1880.

Since the foundation of the Hospital in Philadelphia in 1752, more or less careful and detailed notes of the cases have been taken and preserved; latterly these clinical records have been more ample, and all according to one plan, farourable for reference. As the hospital has long taken a leading position in the United States, the managers desired that some account of the results obtained there should be published, and the volume before us is the result. The report deals with surgical cases only, and in separate chapters a short account is given of the modes of treatment adopted for various diseases and injuries, and a statistical table of all the cases of such disease or injury is appended. Cases of special interest are detailed more fully. The volume affords abundant evidence, if such were needed, that the surgical practice of the hospital is and has been of a high order. In glancing over the chapters we have not met with much calling for special comment from us. In the treatment of wounds Listerism appears not to be usually adopted, and an immunity from pyæmia and erysipelas arising in the hospital is claimed as the result of a perfect system of ventilation of the wards, and cleanliness in dressing. Several cases of elephantiasis are noted, in one of which, after ligature of the femoral artery had failed to produce a cure, excision of a portion of the great sciatic nerve in the thigh was followed by very marked improvement; and this treatment, rather than ligature of the artery, is recommended as more certain to be followed by a permanent good result.

WE have also received the following:- The Cobham Journals. By E. A, Ormerod. (E. Stanford.)-The Human Body and its Functions. By Dr. H. S. Paterson. (Hodder and Stoughton.) - Hay Fever. By Dr. C. H. Blackley. Second Edition. (Baillière, Tindall, and Cox.) - Homoepathy : What is it? By Dr. A. B. Palmer. (Davis, Detroit.) - Heat a mode of Motion. By John Tyndall, D.C.L. \&c. Sixth Edition. (Longmans.) - New Greek Delectus. By H. M. Wilkins, M.A. (Longmans.)-A Guide to the Practical Examination of the Urine. By Dr. J. Tuson. Third Edition. (Lindsay and Blakiston, Philadelphia.) - On Insufficiency of the Aortic Valves. By Dr. J. Cockle. (Baillière, Tindall, and Cox.) - How to Feed an Infant. By Dr. Benson Baker. (Baillière, Tindall, and Cox.) - A Winter Tour through India, Burmah, and the Straits. By H. E. Falk. (Longmans.) - The Surgeon's Pocket-book. By Surgeon-Major J. H. Porter. Second Edition. (Griffin and Co.) - Ward and Lock's Long Life Series. (4 vols.) A Guide to the Examination of the Urine. By Dr. J. W. Legge. Fifth Edition. (H. K. Lewis.) - Water, its Impurities and Purification. Seventh Edition.--Pharmacopceia of the British Hospital for Diseases of the Skin. Edited by B. Squire, M.B. Second Edition. (Churchill.)

\section{DOCTORS IN PARLIAMENT.}

\section{To the Editor of THE LANCET.}

SrR,-The new Parliament has been complete for some little time, and a word or two may not be inopportune with regard to the medical element in its composition. The first thing that strikes one is, that whatever may be the quality of that element, the quantity is anything but excessive. The legal profession, not more learned or more numerous, or of greater legislative importance than the medical, has nine times as many representatives in the House of Commons, besides an important contingent in the Lords. That this is a misfortune to the medical profession no one can doubt; that it is a loss to the public, The Times and other organs of opinion have decidedly affirmed. It may be noted that the deficiency is due chiefly to the larger division of the Lnited Kingdon, Ireland sending two doctors to Parliament, Scotland three, and England none. This is a state of things at once curious and uusatisfactory. That of the twenty thousand learned and scientific men who constitute the medical profession in England not one should be found even to offer himself for Parliament during the late general election, is a phenomenon worthy of more than passing notice. It is a phenomenon all the more striking when contrasted with the animated interest displayed in politics by the medical profession in France, Germany, and other Continental countries. Such an attitude may satisfy the older physicians and surgeons, but cannot be other than disappointing to those younger men who, along with their medical learning, have imbibed some small portion of the spirit of literature and philosophy. They are not content to be the mere padding of social and political life. It is an offence to them that eminent members of their own profession should be in the hackground whilst men of the "Gorgius Midas" type, whose only claim to notice is that of wealth or vulgar self-assertion, should ruffle themselves in high places and pose as imperial law-makers.

It is evident from the tone of the Press that the doctors alone are responsible. There is no unwillingness on the part of the public to be represented by medical men : rather is there an urgent outcry for scientific and sanilary legislators. Why is there, then, so feeble a response to so im perative a demand? Are the doctors so much oppressed with a sense of their own deficiency that they dare not adventure their bark on the troubled waters of political life? If so, they may take courage. That which rich traders can do with so much apparent satisfaction to themselves and so little injury to their country may surely be done by men whose minds have been trained to use the patient, observant, and accurate methods of science. It seems probable, however, that it is no overstrained modesty which prevents physicians and surgeons from entering upon a parliamentary career. More frequently it is the result of a devotion to professional work so absolute as to produce in the subjects of it great narrowness of mind and want of sympathy with general, social, and political questions. Such devotion may be pecuniarily and professionally profitable to the individual, but it is highly disadvantageous to the community at large. It has, moreover, the effect of dwarfing the whole profession in public estımation. Some of the eminent physicians and surgeons of the present day are men of robust and manly character, whose natural characteristics have been developed in a high degree by severe and prolonged training, and they may titly be considered great, and illustrious men. But take them away from their own line of things, and they will be seen to hold a very modest place in the public judgment.

There is au unfortunate feeling among medical men that they should keep strictly to their own department, and not mix themselves up with the turmoil and excitement of political life. There is an uncertainty, too, as to what might be the effect on their professional gains if they took a decided stand and gave up a portion of their time to political duties. Now, whilst this feeling may be strictly in accordance with the dictates of a cold and worldly prudence, it by no means commends itself to a noble and generous patriotism, and one would be very unwilling to think that there are few or none in the medical profession who pessess the highest attributes of mankind. Be this as it may, it is certain that the profession has missed a great opportunity, and has surprised and disappointed the public more than a little. Never yet have we seemed to see and possess that social and political position which is our just due, and which it is so inportant for the public welfare that we should possess. That lawyers and divines should sit in the highest couvcil of the nation, whilst men who study the very reason and nature of all things, theology and law not excepted, should be forbidden to approach those high precincts is an anachronism and an absurdity. But who is at fault? If we take no interest in imperial politics, if we show no legislative capacity, if we prefer a narrow, though, perhaps, profitable exclusiveness to a broader and more varied range of duty, we ought neither to wonder nor complain if we are taken at our own valuation.

\section{I an, Sir, yours, Sc.,}

G. W. POTTER, M.D. EdIN.

Grosvenor-road, N., May 24th, 1880 . 